Tidsskrift for universiteternes efter- og videreuddannelse (ISSN 1603-5518). 2 årgang, nr. 6, 2005

\title{
Mindre fremmøde, større aktivitet, højere kvalitet
}

- introduktion af IT-støttede undervisningsformer i en masteruddannelse. Baggrund, teori og praktiske erfaringer

\author{
Bodil Bruun \\ Lektor, MIL \\ Mulernes Legatskole \\ Bodil Bruun@skolekom.dk \\ http://www.mulerne-gym.dk
}

\author{
Susanne Hjorth Hansen \\ Adjunkt, MIL \\ Radiografuddannelsen \\ Sundheds CVU Aalborg \\ susanne.hjorth.hansen@scvua.dk \\ http://www.scvua.dk
}

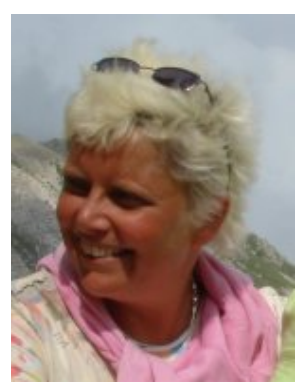

\section{Jakob Ousager}

E-læringsvejleder, ph.d.-stipendiat, MIL

Enheden for Uddannelsesudvikling

og Forskningsenheden Helbred, Menneske og Samfund

Sundhedsvidenskab, Syddansk Universitet

jousager@health.sdu.dk

http://www.hms.sdu.dk/JakobOusager
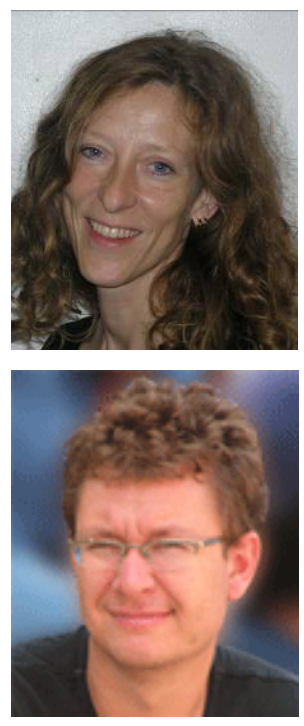

Vi - forfatterne - kender hinanden fra Masteruddannelsen i Ikt og Læring (MIL), som er en uddannelse under It-Vest mellem Aalborg Universitet, Århus Universitet, Danmarks Pcedagogiske Universitet, Copenhagen Business School og Roskilde Universitetscenter.

I vores feelles masterprojektet: The Missing Link - i gråzonen mellem uddannelsesmål og undervisningsformer, udviklede vi, med udgangspunkt i et konstruktivistisk syn på læring og undervisning, en generel model til analyse af sammenhæeng mellem uddannelsesmål og undervisningsformer. Samtidig udviklede vi en 'vcerktøjskasse', som kan anvendes til at lave konkrete anbefalinger med henblik på at øge sammenhœng mellem mål og undervisningsmetoder i uddannelse.

Nœrvœrende artikel redegør for et udviklingsprojekt, hvor model og værktøjskasse er anvendt i praksis: Vi har analyseret og foreslået cendringer til en uddannelse, og uddannelsens studieleder og undervisere har implementeret og evalueret.

Underviserne og studielederen har haft lejlighed til at se artiklen igennem - men perspektivet i artiklen er vores, og det samme gcelder ansvaret for fremstillingen af de praktiske erfaringer, herunder tolkningen af evalueringsresultaterne. 


\begin{abstract}
Abstrakt
Masteruddannelsen i rehabilitering, som udbydes af Det Sundhedsvidenskabelige Fakultet ved Syddansk Universitet, har netop afsluttet et udviklingsprojekt, hvor en del af uddannelsen gennemførtes med intensiv brug af IT-støttede undervisningsformer.

Udviklingsprojektet blev udført i samarbejde mellem uddannelsens studieleder og undervisere og en konsulentgruppe. Ved hjælp af konsulentgruppens 'Missing link-model', som fokuserer stærkt på sammenhæng mellem uddannelsesmål og undervisningsformer, blev udviklet et undervisningsforløb, hvor få tilstedeværelsesseminarer veksler med on-line perioder med stor studenteraktivitet.
\end{abstract}

Forløbet blev omsat til praksis i efteråret 2005. Projektet har samlet set været en succes; men der er også høstet erfaringer, der kan forbedre fremtidige lignende projekter.

\title{
Indledning
}

\section{Deltagerne og processen}

Projektet er udført i perioden oktober 2004 til oktober 2005 i samarbejde mellem studieleder for masteruddannelserne i hhv. gerontologi og rehabilitering, Christine Swane, og en konsulentgruppe bestående af denne artikels forfattere. Konsulentgruppens opgave var at lave et forberedende analysearbejde og give anbefalinger til en ny undervisningstilrettelæggelse. Studielederens opgave var i første omgang at følge analysearbejdet og udfærdigelsen af anbefalingerne for at sikre, at resultatet ville blive relevant, anvendeligt og realiserbart. Den efterfølgende - og største - opgave for studielederen var at lede implementeringen af anbefalingerne i samarbejde med underviserne på uddannelsen samt e-læringsvejlederen.

Projektet er nu afsluttet med den faktiske gennemførsel af et uddannelsesmodul med den nye tilrettelæggelse. De studerende har evalueret forløbet både mundtligt og via et spørgeskema, ligesom underviserne, studielederen og e-læringsvejlederen har evalueret såvel de enkelte kurser som det samlede forløb.

Den indledende analyse, udfærdigelsen af anbefalinger for den nye struktur, samt erfaringer fra anbefalingernes implementering med efterfølgende evaluering danner grundlag for denne artikel.

\section{Ønske om fleksibilitet og højt fagligt niveau}

Uddannelserne Master i Rehabilitering (MR) og Master i Gerontologi (MG) er unge, dvs relativt nystartede, og uden egentlige problemer - men med en naturlig interesse i løbende at udvikle sig med henblik på at sikre en høj faglig kvalitet. Særlig er der fokus på at sikre de studerendes muligheder for faglig fordybelse, og for at øge fleksibiliteten for de studerende, som typisk har både fuldtidsjob og familieliv at passe parallelt med deres studier.

På den baggrund fremsatte uddannelserne i efteråret 2004 ønske om at ændre strukturen, så de studerende i højere grad selv fik mulighed for at planlægge studierne. Uddannelserne så muligheder i blended learning, dvs en tilrettelæggelse med både tilstedeværelseskurser og online kurser, men var samtidig usikre på, hvordan man planlægger et sådant forløb, når man ikke vil give køb på den faglige kvalitet i uddannelsen - tværtimod.

Som for de fleste andre uddannelser var målene og det faglige indhold for masteruddannelserne beskrevet i ret præcise termer, mens de undervisningsmetoder, der blev anvendt i uddannelserne, enten ikke var omtalt eller kun beskrevet sparsomt med enkeltord som fx "fore- 
Tidsskrift for universiteternes efter- og videreuddannelse (ISSN 1603-5518). 2 årgang, nr. 6, 2005 læsning”. Valg af undervisningsformer på de enkelte kurser var op til underviseren selv, og undervisningsformerne var ikke koordineret indbyrdes mellem underviserne/kurserne på uddannelsen.

Tilsvarende var det op til underviserne selv at vurdere, hvordan Universitetets elæringsplatform skulle anvendes. Typisk blev den brugt til at distribuere materiale som $f x$ en Powerpoint-fil til de studerende efter et weekendseminar med foredrag, og til at aflevere opgaver. Der var også tilbud til de studerende om at få et grupperum (med begrænset funktionalitet). Men elæringsplatformen blev ikke brugt i egentlig faglig interaktionssammenhæng i forbindelse med undervisningen.

\section{Fakta: Om masteruddannelserne i rehabilitering og gerontologi}

Uddannelserne MR og MG blev etableret ved Syddansk Universitet i 2002. Uddannelserne er tilrettelagt som deltidsstudier over 2 år svarende til 1 årsværk, 60 ECTS. Uddannelserne har samme opbygning: 4 obligatoriske og 2 valgfrie moduler, som afsluttes med prøve, samt sommerskole, metodeworkshops og masterprojekt. Undervisningen foregår dels på 2 ugekurser og dels på 23 seminarer af 2-5 dages varighed. Anvendte undervisningsformer er foredrag, dialog, problemorienteret gruppearbejde og øvelsesundervisning. Det oplyses, at det er helt nødvendigt at anvende 15-20 timer ugentligt til individuel og eventuel gruppevis læsning og øvelse ud over seminarerne. I tilknytning til seminarer og vejledning til masterprojekt forudsættes, at de studerende er i dialog med undervisere og medstuderende via IT-støtte, baseret på Blackboard-systemet (Bb).

\section{'Missing link-modellen' anvendt: Fra uddannelsesmål til undervisningsformer}

Vores udgangspunkt for at indgå samarbejde med MR og MG var overbevisningen om, at man kan optimere en uddannelsesproces - dvs de studerendes læring - ved at følge grundprincippet om, at der skal være sammenhæng mellem uddannelsesmål, undervisningsformer og eksamensformer. Dette udgangspunkt er selvfølgelig ikke nyt; ideelt set er det udgangspunkt for enhver didaktisk og metodisk virksomhed. Men det har vist sig, at det ikke er så ligetil, når metodikken også inddrager brug af e-læring (Mathiasen 2002).

Vores bidrag i denne forbindelse er, at vi har udviklet en model, der gennem analyse af uddannelsesmålene kan komme med bud på hvilke typer af undervisningsformer, med eller uden IT, der vil kunne støtte de studerendes faglige udvikling i retning af disse mål. Det er den model, vi har kaldt 'Missing link-modellen'. Missing link-modellen - og dens teoretiske baggrund - beskrives lidt mere udførligt senere i denne artikel. Men i den helt korte version går modellen ud på, at vi som det første bestræber os på at klarlægge hvilke uddannelsesmål, der efterstræbes i den uddannelse eller undervisningsaktivitet, der er i fokus. Vi opererer her med tre typer af uddannelsesmål, som kan være efterstræbt i større eller mindre udstrækning, nemlig kvalifikationer (her forstået som faktuel viden), kompetencer (relationskompetence, refleksionskompetence og meningskompetence) og faglig kommunikation. Næste trin er at bruge samme optik til at vurdere de undervisningsformer, der aktuelt er i brug. Målet er her at vurdere, om de anvendte undervisningsformer særligt kan formodes at fremme kvalifikationer, kompetencer og/eller faglig kommunikation. Tredje og sidste trin i Missing link-pakken går ud på - bl.a. ved brug af en grafisk model - at sammenholde resultaterne af analyserne af uddannelsesmål og undervisningsformer. På den baggrund kan vi foreslå undervisningsformer, som vi mener at kunne argumentere for passer godt til de uddannelsesmål, der efterstræbes.

De to masteruddannelsers fælles ledelse var som nævnt indstillet på at udvikle uddannelserne - men det skulle (naturligvis!) ske uden at udvide uddannelsernes budgetter væsentligt. Udgangspunktet for vores arbejde var altså, at vi skulle foreslå en strukturændring baseret på en omprioritering af midlerne. 
Tidsskrift for universiteternes efter- og videreuddannelse (ISSN 1603-5518). 2 årgang, nr. 6, 2005

Det var derfor nødvendigt for os at få præciseret formålet med uddannelserne, at få kortlagt de praktiske muligheder i brugen af den e-læringsplatform, der var til rådighed, og endelig at få overblik over de forhåndenværende midler. På baggrund af denne analyse udarbejdede vi anbefalinger til, hvordan uddannelsernes fælles Modul 1 skulle struktureres, og hvilke undervisningsformer, der skulle anvendes i modulets forskellige dele.

Uddannelsernes studienævn traf beslutning om at give vores anbefalinger en chance for at bevise deres anvendelighed. Desværre viste det sig, at der ikke kunne startes en årgang af Masteruddannelsen i Gerontologi i efteråret 2005. Men der blev startet en årgang af Masteruddannelsen i Rehabilitering - og her blev uddannelsens Modul 1 gennemført efter den nye model. I det følgende beskrives udviklingsprojektet som det var, nemlig rettet mod de to uddannelsers fælles Modul 1. Men beskrivelsen af erfaringerne fra de praktiske erfaringer stammer altså af gode grunde kun fra gennemførelsen af Modul 1 på Masteruddannelsen i Rehabilitering årgang 2005.

\section{Udviklingsprojektets faser}

\section{Masteruddannelsernes Modul 1 ved projektstarten}

Projektets første mål var at fremsætte anbefalinger til øget anvendelse af IT i undervisningen i MR- og MG-uddannelsernes fælles Modul 1. Modulet handler hovedsageligt om forskningsmetodologi, men rummer også introduktioner til centrale begreber i henholdsvis gerontologi og rehabilitering.

Modul 1 strakte sig (og strækker sig stadig) over 8 uger. Som det fremgår af figur 1, var undervisningen i den oprindelige organisering centreret om tre weekend-seminarer (8 seminardage), og blev afsluttende eksamineret ved individuelle, skriftlige hjemmeopgaver.

\begin{tabular}{|l|l|l|c|}
\hline \multicolumn{1}{|c|}{ Uge 1 } & \multicolumn{1}{|c|}{ Uge 2 } & Uge 3 & Uge 4 \\
\hline 1. seminar: 2 dage & $\begin{array}{c}\text { Lasning, Bb-dialog med } \\
\text { undervisere og medstude- } \\
\text { rende }\end{array}$ & $\begin{array}{c}\text { 2. seminar: 4 dage } \\
\text { Fagspecifikke introduk- } \\
\text { tioner }\end{array}$ & $\begin{array}{c}\text { Lasning, Bb-dialog med } \\
\text { undervisere og medstude- } \\
\text { rende }\end{array}$ \\
\hline Foredrag med dialog & \multicolumn{1}{|l|}{$\begin{array}{c}\text { Litteratursøgning } \\
\text { Intro og praktisk træning i } \\
\text { brug af faglige databaser }\end{array}$} & \\
\hline & $\begin{array}{l}\text { Kvalitative metoder } \\
\text { Forelæsning, øvelser, } \\
\text { præsentationer }\end{array}$ & \\
\hline & $\begin{array}{l}\text { Kvantitative metoder } \\
\text { Forelæsning, diskussion, } \\
\text { gruppearbejde }\end{array}$ & \\
\hline
\end{tabular}




\begin{tabular}{|c|l|c|c|}
\hline Uge 5 & \multicolumn{1}{|c|}{ Uge 6 } & Uge 7 & Uge 8 \\
\hline $\begin{array}{c}\text { Lesning, Bb-dialog med } \\
\text { undervisere og medstude- } \\
\text { rende }\end{array}$ & 3. seminar: 2 dage & $\begin{array}{c}\text { Lesning, Bb-dialog med } \\
\text { undervisere og medstude- } \\
\text { rende }\end{array}$ & $\begin{array}{c}\text { Individuel opgaveskriv- } \\
\text { ning }\end{array}$ \\
\hline & $\begin{array}{l}\text { Biostatistik } \\
\text { Forelæsning, øvelser }\end{array}$ & $\begin{array}{l}\text { Individuel skriftlig hjem- } \\
\text { meopgave. Den studeren- } \\
\text { de skal demonstrere viden } \\
\text { om kvalitativ metode, } \\
\text { kvantitativ metode og } \\
\text { biostatistik. }\end{array}$ \\
\hline & $\begin{array}{l}\text { Videnskabsteori og } \\
\text { kritisk litteraturlæsning } \\
\text { Forelæsning, gruppeøvel- } \\
\text { ser, præsentationer }\end{array}$ & & \\
\hline
\end{tabular}

Figur 1: Overblik over den oprindelige strukturering af masteruddannelsernes Modul 1.

Princippet i tilrettelæggelsen var, at koncentreret undervisning om de faglige og metodiske emner på seminarerne efterfulgtes af læsning og Bb-støttet dialog - dvs dialog med anvendelse af e-læringsplatformen Blackboard (Bb). Det var op til de studerende selv i læsegrupper og til den enkelte underviser hvordan denne dialog konkret blev indledt og vedligeholdt

\section{Analyse - Potentialer for udvikling af undervisningsformer}

Analysen af uddannelsesmål og undervisningsformer i de to masteruddannelsers Modul 1 påviste ikke uhensigtsmæssigheder eller uoverensstemmelser mellem mål og undervisningsmetoder; der var faktisk fin sammenhæng. Samtidig kunne det ikke udelukkes, at der gemte sig uhensigtsmæssigheder bag det faktum, at undervisningsformerne var beskrevet så bredt, at det var vanskeligt at gennemskue, om de enkelte, konkrete undervisningsaktiviteter var optimale i forhold til målene. Under alle omstændigheder viste analysen, at IT-støttede undervisningsformer kun i ringe omfang var integreret i uddannelserne. Det var derfor vurderingen, at sammenhængen mellem undervisning og mål alt andet lige kunne styrkes ved at gennemføre ændringer med henblik på mere intensiv udnyttelse af IT-støttede undervisningsformer. Især syntes der at være uudnyttede potentialer på følgende punkter:

1. Både studerendes og underviseres tid ville kunne udnyttes mere intensivt og fleksibelt, hvis mængden af 'fremmøde-undervisning' reduceredes, samtidig med at mængden af organiseret online arbejde øgedes.

2. De studerende ville kunne gives bedre forudsætninger for et godt læringsudbytte, hvis undervisningen fik et mere målrettet og eksplicit design, ikke mindst med henblik på at give bedre rum til studerendes refleksion over det faglige indhold.

3. De studerendes interaktion og kommunikation med underviserne, hinanden og det faglige stof kunne styrkes og varieres gennem intensiveret brug af de værktøjer til elektroniske konferencer, der er til rådighed i e-læringsplatformen.

4. De studerendes læringsudbytte kunne øges - både hvad angår udvikling af praktiske studiefærdigheder og hvad angår evnen og tilskyndelsen til at forholde sig selvstændigt og kritisk til uddannelsens indhold - hvis modulet blev reorganiseret, så det i højere grad sigter på at gøre de studerende til selvstændige, kvalificerede og kritiske brugere af e-læringsplatformen. 


\section{Anbefalinger til øget anvendelse af IT i undervisning}

På baggrund af denne analyse kunne vi fremlægge følgende anbefalinger til ændret tilrettelæggelse af Modul 1:

\section{Fra tre til to seminarer}

Det foreslås, at kursusforløbet i Modul 1 omstruktureres således, at der kun afholdes to seminarer, og at der til gengæld indlægges strukturerede online perioder op til og mellem seminarerne. Den nye struktur skal sætte rammerne for et undervisningsforløb, som giver bedre plads til refleksion, og som i højere grad inviterer de studerende til aktivt at anvende og dermed forholde sig til det faglige indhold i modulets kurser.

\section{Fra kursus i litteratursøgning til bedre studieintroduktion inkl. introduktion til e- læringsplatformen (Blackboard)}

De studerende bør gives en bedre og mere grundig introduktion til e-læringsplatformen Blackboard. Blackboard skal ikke blot bruges til distribution af materialer, men skal fungere som et virtuelt rum, hvor en del af undervisningen foregår, og hvor de studerende får deres daglige gang og føler sig hjemme. Derfor skal de studerende allerede før første seminar i gang med at bruge Blackboard, og der skal gives plads til et egentligt Blackboard-kursus på første seminar. Samtidig kan kurset i litteratursøgning med fordel flyttes til Modul 2, hvor de studerende netop for første gang får brug for dette, nemlig som en kvalifikation i forbindelse med opgaveskrivning/projektarbejde.

\section{Samlede fagspecifikke introduktioner (rehabilitering hhv gerontologi)}

Det foreslås, at de introducerende forelæsninger og diskussioner vedr. hhv gerontologi og rehabilitering gives et mere samlet udtryk. De introducerende forelæsninger er vigtige, fordi de kan fungere som de studerendes udgangspunkt for at diskutere udvalgte faglige elementer med hinanden og med forelæserne. Hermed støttes de studerende i at forholde sig aktivt til fagenes grundbegreber, og dermed i at danne deres individuelle forståelse af begreberne. Men sammenhængen mellem elementerne i hver af de fagspecifikke introduktioner bør tydeliggøres, så det bliver lettere for de studerende at orientere sig i det begrebsmæssige landskab, de præsenteres for. Samtidig bør de studerende gives bedre mulighed for at forberede sig på 1 . seminars fagspecifikke introduktioner gennem udlevering af forelæsningsabstracts og læsevejledninger forud for seminaret.

\section{Fra én afsluttende eksamen til tre del-eksaminer}

Oprindeligt blev Modul 1 evalueret med en samlet skriftlig opgave, som de studerende skulle skrive hjemme i løbet af en uge i slutningen af modulet. Det foreslås, at eksamen i Modul 1 omlægges, så den fremover udgøres af tre mindre prøver i hhv kvantitativ metode, kvalitativ metode og biostatistik. Ved tidsmæssigt at splitte testen op i de tre delområder, får de studerende bedre mulighed for at fordybe sig i de metodiske tilgange enkeltvis. Der bibeholdes en individuel skriftlig opgave som afslutning på modulet; men denne opgave retter sig nu kun mod kurserne i kvalitativ metode og videnskabsteori/kritisk litteraturlæsning. Kurset i kvantitativ metode evalueres via online diskussioner, og kurset i biostatistik evalueres via en 'automatiseret' multiple choice-test.

\section{Bedre 'rum-indretning' i e-læringsplatformen}

Det foreslås, at der oprettes en række rum i Blackboard. Der oprettes i første omgang et helt overordnet master-rum, som de studerende har adgang til og bruger igennem hele uddannel- 
Tidsskrift for universiteternes efter- og videreuddannelse (ISSN 1603-5518). 2 årgang, nr. 6, 2005 sen, et rum for Modul 1, to rum for hhv. det rehabiliterings- og gerontologispecifikke og dertil en række grupperum, som studiegrupperne kontrollerer uden undervisernes indblanding.

Master-rummet skal indeholde information om rammer for uddannelsen (studieordning, love, regler, læseplaner mv), og der skal være adgang til forskellige kommunikations-fora for mere generel og social kommunikation, nemlig "Café", "Studievejledning”, "Sekretariat", "Præsentationer". Det sidste forum skal bruges til en præsentation af samtlige studerende; en præsentation, som de studerende før 1. seminar bliver bedt om at skrive direkte i dette forum, evt. med billede. De studerende skal sammen med meddelelsen om, at de er optaget på uddannelsen, modtage en kort introduktion til Blackboard, som gør dem i stand til at besvare denne opgave.

Modul 1-rummet skal indeholde en materiale-mappe med undermapper, der skal fungere som arkiv for dokumenter og aktive links, samt et eller flere diskussionsfora for hver af de kurser der indgår på Modul 1.

Gruppe-rum giver de studerende adgang til arkivfunktionen, diskussionsfora for asynkron diskussion samt chat for synkron kommunikation. Chatten er et vigtigt redskab på tidspunkter i en gruppes arbejde, hvor der skal tages hurtige beslutninger fx i forbindelse med afklaring af arbejdsfordeling eller diskussion af centrale begreber før selve opgave-skrivningsfasen. De studerende skal selv finde en hensigtsmæssig måde at opbygge arkivsystem og diskussionsfora, hvilket er medvirkende til at de skaber deres eget overblik over uddannelsens elementer.

\section{Fra overordnede anbefalinger til implementering}

Med udgangspunkt i de overordnede anbefalinger udarbejdede vi helt konkrete forslag til en ny tilrettelæggelse af Modul 1, som skitseret i figur 2.

\begin{tabular}{|c|c|c|c|}
\hline Uge 1 & Uge 2 & Uge 3 & Uge 4 \\
\hline Online periode & 1. seminar & Online periode & Online periode \\
\hline \multirow{5}{*}{$\begin{array}{l}\text { Studiestart } \\
\text { Den enkelte studerende } \\
\text { præsenterer sig selv med } \\
\text { indlæg i diskussionsfo- } \\
\text { rum. }\end{array}$} & Studiestart & & \multirow{3}{*}{$\begin{array}{l}\text { Videnskabsteori og } \\
\text { kritisk litteraturlæs- } \\
\text { ning } \\
\text { Forberedelse: Læsning } \\
\text { af artikler og abstracts, } \\
\text { online disk. af artik- } \\
\text { ler/øvelser }\end{array}$} \\
\hline & $\begin{array}{l}\text { Blackboard: Opsamling } \\
\text { på begynderproblemer, }\end{array}$ & & \\
\hline & $\begin{array}{l}\text { introduktion til samar- } \\
\text { bejdsværktøjer. }\end{array}$ & & \\
\hline & Studiestart & & Kvalitative metoder \\
\hline & $\begin{array}{l}\text { Nedsættelse af studie- } \\
\text { grupper. }\end{array}$ & & $\begin{array}{l}\text { Forberedelse til seminar: } \\
\text { læsning af litteratur og } \\
\text { abstracts }\end{array}$ \\
\hline Kvantitative metoder & Kvantitative metoder & Kvantitative metoder & Kvantitative metoder \\
\hline $\begin{array}{l}\text { Forberedelse til seminar: } \\
\text { læsning af litteratur og } \\
\text { abstracts }\end{array}$ & $\begin{array}{l}\text { Introducerende forelæs- } \\
\text { ning }\end{array}$ & $\begin{array}{l}\text { Online gruppediskussio- } \\
\text { ner, afsluttes med grup- } \\
\text { pens opsamling. }\end{array}$ & $\begin{array}{l}\text { Underviseren melder } \\
\text { tilbage i gruppefora. (1. } \\
\text { deleksamen). }\end{array}$ \\
\hline \multirow{2}{*}{$\begin{array}{l}\text { Fagspecifikke intro- } \\
\text { duktioner } \\
\text { Seminarforberedelse: } \\
\text { læsning, abstracts, on- } \\
\text { line diskussioner }\end{array}$} & $\begin{array}{l}\text { Fagspecifikke intro- } \\
\text { duktioner }\end{array}$ & $\begin{array}{l}\text { Fagspecifikke intro- } \\
\text { duktioner }\end{array}$ & \multirow{2}{*}{$\begin{array}{l}\text { Biostatistik } \\
\text { Forberedelse til seminar } \\
\text { - læsning af artikler og } \\
\text { abstracts. }\end{array}$} \\
\hline & $\begin{array}{l}\text { Forelæsninger og di- } \\
\text { skussioner }\end{array}$ & $\begin{array}{l}\text { Afsluttende diskussioner } \\
\text { online }\end{array}$ & \\
\hline
\end{tabular}




\begin{tabular}{|c|c|c|c|}
\hline Uge 5 & Uge 6 & Uge 7 & Uge 8 \\
\hline 2. seminar & Online periode & Online periode & $\begin{array}{l}\text { Individuel opgaveskriv- } \\
\text { ning }\end{array}$ \\
\hline $\begin{array}{l}\text { Videnskabsteori og } \\
\text { kritisk litteraturlæs- } \\
\text { ning } \\
\text { Forelæsning, præsentati- } \\
\text { oner og diskussioner }\end{array}$ & & & \\
\hline $\begin{array}{l}\text { Kvalitative metoder } \\
\text { Introducerende forelæs- } \\
\text { ning }\end{array}$ & $\begin{array}{l}\text { Kvalitative metoder } \\
\text { Online gruppevis di- } \\
\text { skussion af artikler ud } \\
\text { fra faste spørgsmål. } \\
\text { Afsluttes med gruppens } \\
\text { formulering af samlede } \\
\text { kritiske spørgsmål til } \\
\text { artiklen. }\end{array}$ & $\begin{array}{l}\text { Kvalitative metoder } \\
\text { Stud. skal poste min. } 3 \\
\text { reaktioner på andre } \\
\text { gruppers spørgsmål. } \\
\text { Formål: Kritisk tænk- } \\
\text { ning, forberedelse til } 3 . \\
\text { deleksamen. }\end{array}$ & $\begin{array}{l}\text { Kvalitative metoder } \\
\text { 3. deleksamen: Indivi- } \\
\text { duel besvarelse af opga- } \\
\text { ve ud fra ny artikel, men } \\
\text { med samme spørgsmål } \\
\text { som blev stillet ved } \\
\text { indgangen til diskussi- } \\
\text { onsperioden }\end{array}$ \\
\hline \multicolumn{4}{|l|}{$\begin{array}{l}\text { Kvantitative metoder } \\
\text { Opsamlingsforelæsning } \\
\text { baseret på online diskus- } \\
\text { sioner. Afsluttende } \\
\text { diskussion. }\end{array}$} \\
\hline $\begin{array}{l}\text { Biostatistik } \\
\text { Forelæsninger og øvel- } \\
\text { ser. }\end{array}$ & $\begin{array}{l}\text { Biostatistik } \\
\text { Studerende forbereder } \\
\text { sig på MCQ gennem } \\
\text { individuelle øvelser. } \\
\text { Mulighed for diskussi- } \\
\text { on/support fra medstu- } \\
\text { derende og underviser. }\end{array}$ & $\begin{array}{l}\text { Biostatistik } \\
\text { 2. deleksamen.: Indivi- } \\
\text { duel MCQ på Black- } \\
\text { board (tidsbegrænset } \\
\text { periode). Automatisk } \\
\text { tilbagemelding umiddel- } \\
\text { bart efter gennemførelse. }\end{array}$ & \\
\hline
\end{tabular}

Figur 2: Overblik over den foreslåede nye strukturering af masteruddannelsernes Modul 1.

Til brug for det konkrete implementeringsarbejde blev der desuden udarbejdet en plan, som i større detaljer beskriver forslaget til organisering af modulets enkelte dele. Endelig blev de anbefalede rum i Blackboard oprettet og gjort brugervenlige og indflytningsklare.

På den baggrund besluttede studienævnet, at anbefalingerne rent faktisk skulle følges - om end desværre kun ved Masteruddannelsen i Rehabilitering, eftersom Masteruddannelsen i Gerontologi som tidligere omtalt ikke blev oprettet efteråret 2005.

Implementeringsarbejdet blev nu udført af studielederen i samarbejde med undervisergruppen ved modulet. E-læringsvejlederen, dvs. fakultetets uddannelseskonsulent med speciale i elæring, deltog dog i et enkelt underviser-planlægningsmøde lige før semesterstart, og optrådte desuden løbende i en birolle som underviser og supporter på brug af e-læringsplatformen.

\section{Evaluering - og hvad vi kan lære af det}

\section{Evalueringsmetoder}

Efter afslutningen af modulet i oktober 2005 er der blevet gennemført forskellige evalueringer af, hvordan modulet er forløbet. Evalueringerne omfatter

- en 'standard-evaluering', hvor studerende svarer på et spørgeskema med spørgsmål om fx undervisningens relevans og kvalitet, om arbejdsomfang, forventninger, forslag til forbedringer o.lign. Spørgeskemaet indeholder både spørgsmål med Likert-skala og åbne spørgsmål, hvor studerende anonymt kan skrive kommentarer. 
Tidsskrift for universiteternes efter- og videreuddannelse (ISSN 1603-5518). 2 årgang, nr. 6, 2005

- en mundtlig evaluering, hvor de studerende sammen med en af underviserne frit har diskuteret modulets form og indhold. Underviseren har taget referat.

- et undervisermøde, hvor studielederen, underviserne, uddannelsessekretæren og elæringsvejlederen har gennemgået og diskuteret erfaringerne fra modulet

- en sammenligning af standardevalueringens resultater med resultater fra evaluering af tidligere udgaver af modulet

Det er en styrke ved evalueringen, at praktisk taget alle studerende og undervisere er blevet hørt, ligesom også sekretariatsfunktionens perspektiv er repræsenteret. Brugen af standardevalueringsskemaer giver mulighed for med forsigtighed at sammenligne evalueringsresultaterne fra den nye udgave af modulet med evalueringsresultaterne fra tidligere udgaver af modulet.

\section{Evalueringsresultater}

Det, der står tilbage som det mest fremtrædende eller gennemgående i evalueringerne samlet set, er

- at der er stor tilfredshed med modulet generelt

- at organiseringen med intensiv brug af IT blev modtaget meget positivt som fagligt berigende

- at selve det at skulle lære at bruge e-læringsplatformen var en kilde til forvirring og frustrationer

Studerendes evalueringer: Stort arbejde, megen usikkerhed - men det var prisen værd

De studerende udtrykker generelt en stor tilfredshed med modulet: Det har været arbejdskrævende, hårdt og til tider frustrerende - men det har været anstrengelserne værd.

Det IT-støttede didaktiske design opfattes som hensigtsmæssigt, inspirerende og velegnet. Men ser man nærmere på den del af evalueringerne, der handler om den konkrete brug af læringsomgivelsen (Blackboard), så slår det meget tydeligt igennem, at en del - måske mange af de studerende har oplevet det som en stor mundfuld, at skulle lære at orientere sig i og bruge den elektroniske læringsomgivelse oveni alle de øvrige sociale og faglige udfordringer, der er forbundet med at starte på et studie. De studerende fremhæver det som positivt, at de allerede før studiestart fik mulighed for at vænne sig til brugen af systemet. Men de har savnet vejledninger i, hvordan systemet bruges helt konkret.

Det er kun med stort forbehold, at man direkte kan sammenligne resultatet af den kvantitative (Likert-skala) standardevaluering fra den nye udgave af modulet med resultatet fra evalueringen af tidligere udgaver. Men man kan dog konstatere, at næsten alle de studerende, som har gennemgået den nye version af modulet, angiver arbejdspresset og deres egen indsats som 'stor' eller 'meget stor', mens en tredjedel af de studerende fra sidste år angav arbejdspresset som 'midt i mellem'. Samtidig kan man dog også konstatere, at de 'nye' studerende vurderer modulet samlet set i hvert fald lige så godt, og på nogle punkter bedre, end tidligere studerende har vurderet deres version af modulet.

\section{Underviseres evalueringer: Mere arbejde, højere kvalitet}

Underviserne vurderer, at de studerende i dette års udgave af modulet har lært mere og på et højere niveau end ved tidligere udgaver af modulet. De vurderer videre, at de studerende har været særdeles aktive og entusiastiske i deres brug af de elektroniske diskussionsfora, og at den større vægt på gruppearbejde har øget det faglige niveau generelt. At det faglige niveau er øget, har bl.a. kunnet ses af kvaliteten af de arbejder, de studerende har afleveret. Underviser- 
Tidsskrift for universiteternes efter- og videreuddannelse (ISSN 1603-5518). 2 årgang, nr. 6, 2005 ne vurderer forsigtigt, at det højere faglige niveau i vid udstrækning skyldes det nye didaktiske design - men med det forbehold, at dette års studerende jo også simpelthen kan være meget dygtige.

Ifølge underviserne har det nye didaktiske design ikke kun gjort de studerende mere aktive: Også underviserne selv har fået mere at lave. Det skyldes ikke mindst, at det simpelthen tager lang tid, hvis eller når man som underviser vil følge med i de diskussioner, de studerende fører i de elektroniske diskussionsfora. Men det øgede tidsforbrug modsvares også af højere kvalitet, mener underviserne, som alle udtrykker meget stor tilfredshed med den nye undervisningsform. En underviser siger selv, at han har været skeptisk overfor 'e-læring' i almindelighed, og derfor også overfor netop dette projekt. Men hverken han eller andre i undervisergruppen ønsker nu at gå tilbage til det oprindelige, mere konventionelle didaktiske design.

\section{Evaluering fra administrativt personale: Mindre arbejde, mere usikkerhed}

I sekretariatet har den nuværende udgave af modulet været mindre tidskrævende at arbejde med end tidligere. Designet af uddannelsens 'rum' i e-læringsværktøjet har virket effektivt og efter hensigten.

Til gengæld melder uddannelsessekretæren også, at hun har brugt en del tid på at tale i telefon med studerende, som har henvendt sig med frustrationer, der typisk har drejet sig om 'startvanskeligheder' vedrørende brugen af Blackboard eller om forvirring hos de studerende om, hvad der konkret forventedes af dem i et bestemt forløb i modulet. Ud fra telefonsamtalerne med de studerende er det sekretærens opfattelse, at studerende oftere end tidligere har stået med spørgsmål af typen ”Hjælp - hvad er det så lige, jeg skal gøre nu?!”

\section{En succes med plads til forbedringer}

Den væsentligste lære, vi kan uddrage af evalueringen, er, at det hele bestemt har været umagen værd! De anbefalinger, der blev givet i konsulentrapporten, har været gennemførlige, er blevet vel modtaget af alle parter, og ser ud til at have haft de ønskede virkninger. Men - der er naturligvis plads til forbedringer:

\section{Bedre introduktion til brug af e-læringsplatformen}

Den væsentligste anke fra de studerende har været den usikkerhed, de har oplevet i forbindelsen ved at skulle lære at bruge e-læringsplatformen. Alligevel vil vi fastholde, at den 'introduktions-strategi', der har været fulgt, faktisk er den rigtige, som også skal følges fremover: De studerende skal kastes ud i at bruge systemet så tidligt som muligt, de skal have inspiration til anvendelsesmuligheder ("Vidste I, at man også kan...”), og de skal støttes i selv at finde ud af, hvordan man så gør helt konkret. Men vi må erkende, at det sidste punkt - støtten til de studerende, som har haft svært ved at finde vej i systemet - ikke har været god eller tilstrækkelig nok. En forbedring kunne bestå i, at der ved de første seminarer indlægges valgfrie Blackboard-workshops, hvor studerende kan få meget konkrete hands-on demonstrationer af nyttige funktioner i e-læringsværktøjet. En anden forbedring kunne bestå i, at anvendeligheden og synligheden af SDUs almene supportværktøj til e-læringsplatformen forbedres.

\section{Tydeliggørelse af forventninger til de studerende}

Der er gjort meget for at sikre, at de studerende ikke skulle blive for forvirrede over de forskellige krav, der stilles til dem igennem modulet: Det har ikke været overset, at når der opstilles klare rammer, som de studerende skal udfolde sig indenfor ( $\mathrm{fx}$ med angivelse af forskellige diskussionsaktiviteter, der skal foregå i bestemte perioder), så skal disse rammer også oplyses klart og tydeligt.

Alligevel er der opstået usikkerhed hos nogle studerende om, hvad der helt konkret forventedes af dem. En del af usikkerheden kan måske forklares ved, at det er en uvant situation for de 
Tidsskrift for universiteternes efter- og videreuddannelse (ISSN 1603-5518). 2 årgang, nr. 6, 2005

fleste at skulle bestå en del af et undervisningsforløb gennem fx deltagelse i online diskussioner. Men det må alligevel vurderes, om informationen til de studerende skal være endnu klarere, så den formentligt uundgåelige usikkerhed hos nystartede studerende reduceres så meget som muligt.

\section{Bedre beregning eller reduktion af underviseres tidsforbrug?}

I de anbefalinger, der ligger til grund for den nye udformning af undervisningsmodulet, er vi gået ud fra, at undervisernes tidsforbrug skulle være uændret. Ganske vist skal underviserne bruge tid på at kommentere indlæg i diskussionsfora, men til gengæld skal de bruge mindre tid end tidligere på tilstedeværelsesundervisning. I praksis viser det sig, ifølge undervisernes egen vurdering, at disse forudsætninger ikke holder stik - deres tidsforbrug er alt andet lige blevet større.

Dette problem kan indlysende nok løses på to måder: Enten ved at acceptere, at bedre kvalitet koster, og at der derfor skal afsættes flere underviserressourcer. Eller ved at have mere fokus på at begrænse de af undervisernes aktiviteter, der er mest tidskrævende, hvilket i praksis vil sige den aktive deltagelse i diskussionsfora. Det sidste kan, vurderer vi, godt lade sig gøre men det må naturligvis bero på en nærmere analyse og efterprøvning.

Det hører dog også med til historien, at e-læringsforløb kræver en stram struktur, hvor alle detaljer skal planlægges og koordineres. Dvs. at planlægningsfasen er krævende, og kan for den enkelte underviser blive uforholdsmæssigt omfattende, hvis ikke der til uddannelsen er knyttet en person, der varetager opsætning af rammerne for e-læringsforløbet, herunder indretning af og introduktion til den e-læringsplatform, der anvendes.

\section{Mere om 'Missing link-modellen'}

\section{Analysemodellen nærmere beskrevet}

Udgangspunktet for vores analysemodel er den antagelse, at de studerende får den bedste undervisning, hvis der er sammenhæng mellem de uddannelsesmål, som uddannelsesinstitutionen sætter op, og de undervisningsformer, der anvendes i de forskellige kurser, som uddannelsen er sammensat af.

Vores bidrag til uddannelsestilrettelæggelsen er altså for det første, at vi analyserer og sammenligner uddannelsesmål og undervisningsformer for at afgøre, om de eksisterende undervisningsformer kan antages at understøtte den studerende i at nå uddannelsesmålene eller ej altså om der var sammenhæng mellem uddannelsesmål og undervisningsformer.

For det andet opstiller vi på baggrund af ovenstående analyse anbefalinger til, hvordan undervisningsformerne ved at udnytte IT kan reorganiseres for yderligere at understøtte de opstillede uddannelsesmål. Disse anbefalinger koncentrerer sig naturligvis om de dele af den samlede undervisning eller uddannelse, hvor forbedringspotentialet ser ud til at være størst. Anbefalingerne i det konkrete projekt med reorganisering af undervisningsformer i de to masteruddannelser fokuserer, som det fremgår, på at drage nytte af øget brug af IT-støttede undervisningsformer.

Tidligere undersøgelser har vist, at variation i undervisningsformer kan være med til at øge de studerendes muligheder for læring, idet variation øger de studerendes motivation for deltagelse i undervisningen både på uddannelsesstedet og i deres forberedelse, men også fordi ingen studerende lærer lige meget gennem hver af de undervisningsformer, de stifter bekendtskab med (Poulsen 2003). Vores anbefalinger til IT-støttede undervisningsformer har derfor fokus på netop at fremme variation i undervisningsformerne. Det er tilstræbt at tilrettelægge undervisningen på en sådan måde, at de studerende får så gode og varierede muligheder, som det 
Tidsskrift for universiteternes efter- og videreuddannelse (ISSN 1603-5518). 2 årgang, nr. 6, 2005 kan lade sig gøre, for at 'koble sig på' de læreprocesser, som undervisningen gerne skulle sætte i gang.

\section{Undervisning og læring}

Vi tager afsæt i en konstruktivistisk opfattelse af undervisning og læring, idet vi opfatter undervisning som kommunikation med det særlige sigte at stimulere læring, og læring som en forandring af individets mentale strukturer.

Undervisning kan foranledige, at den studerende lytter og evt. kommer med bidrag til kommunikationen og derigennem får feedback. Undervisning kan altså påvirke den studerende til at skabe forandringer i sine bevidsthedsstrukturer, dvs anspore til læring. Undervisningens form - kommunikationsformen - er afgørende for hvilke muligheder den studerende rent faktisk har for at bidrage til kommunikationen og få feedback.

\section{Uddannelsesmål: Kvalifikationer, kompetencer og faglig kommunikation}

Vi skelner mellem kvalifikationer og kompetencer som to former for uddannelsesmål:

Kvalifikation forstår vi som besiddelse af faktuel viden, viden om noget. At vide noget, dvs at have kvalifikationer, er en forudsætning for at kunne noget, at kunne handle kompetent.

Kompetence forstås her som en samlebetegnelse for de tre kompetenceformer relationskompetence, refleksionskompetence og meningskompetence: Relationskompetence handler om at kunne kommunikere med den anden, ud fra en forståelse af den andens perspektiv, uden at overtage den andens perspektiv. Relationskompetence er forudsætning for at kunne kommunikere med andre, uanset de repræsenterer andre dele af samfundet eller en anden kultur end én selv. Refleksionskompetence handler om at iagttage sig selv mens man kommunikerer med den anden, så man ser sig selv i den andens perspektiv, samtidig med at man er bevidst om sit eget perspektiv. Refleksionskompetence er forudsætning for løbende at kunne fortolke og forandre egne kriterier for iagttagelse, kommunikation og handling. Meningskompetence handler om at kunne identificere fælles meningshorisont og værdier, som ikke alene hentes hos én af kommunikationens parter, men som kan forandres kontinuerligt. Meningskompetence er forudsætning for at kunne respektere et fælles meningsgrundlag (Qvortrup 2003).

En tredje form for uddannelsesmål er faglig kommunikation. Kommunikation er et aspekt, der er relateret til alle kompetenceformerne. Det at kunne kommunikere i faglige sammenhænge opfatter vi som et uddannelsesmål, der går på tværs af kvalifikations/kompetenceskematikken.

\section{Læring gennem kommunikation}

Vi går ud fra en grundlæggende antagelse om, at man lerer gennem kommunikation og feedback, og at man kan kommunikere på mange måder - fx ved at lytte (læse) og prøve at forstå, at tale eller diskutere med andre etc. Kommunikation forstås som bestående af tre dele, nemlig af den information der skal meddeles, den måde informationen meddeles på samt den måde meddelelsen forstås på af den, som meddelelsen er henvendt til. Den information, der ligger i fx en 'udtalelse' forstås forskelligt af de tilhørere, der er til stede - og ikke nødvendigvis præcis som den er tænkt fra 'udtalerens' side. Men gennem udveksling af synspunkter kan man nå frem til noget, der ligner en fcelles forståelse af informationen. I relation til undervisning er det jo afgørende, at de studerende forstår de begreber, underviseren lægger frem, på nogenlunde samme måde som underviseren gør. Derfor er det også afgørende, at undervisningsformen befordrer eller i hvert fald muliggør den udveksling af synspunkter, der kan bidrage til etableringen af en tilnærmelsesvis fælles forståelsesramme (Rasmussen 2004). 


\section{Kategorisering af undervisningsformer}

Med det udgangspunkt deles undervisningsformerne op i kategorier alt efter den studerendes mulighed for at kunne 'lytte' til andre, selv 'udtale' sig og udveksle synspunkter med en eller flere. Undervisningsformerne er inddelt i 4 kategorier, nemlig:

- 1-M: Den studerendes kommunikation med materiale, fx metoder hvor den studerende læser litteratur, søger information på internettet, læser noter som underviseren har lagt ud på nettet, anvender faglige softwareprogrammer o. lign.

- 1-1: Den studerendes kommunikation med en anden person, fx gruppearbejde i par, en studerende får vejledning af sin vejleder - face-to-face (fysisk tilstedeværelse) eller online, to studerende arbejder sammen omkring et softwareprogram, chat mellem to studerende vedr. en fælles opgave etc.

- 1-mange: En undervisers kommunikation med flere studerende, fx forelæsninger face-toface eller online, holdundervisning, studerende der præsenterer temaer for hinanden o. lign.

- Mange-mange: Flere studerendes (og evt. undervisers) indbyrdes kommunikation, fx i gruppearbejde i større grupper, projektarbejde, online diskussionsfora eller chat (asynkron og synkron kommunikation) med flere deltagere (Poulsen 2001).

Hver af disse 4 kategorier af undervisningsformer stimulerer den studerende i forskellig grad til hhv. at tilegne sig kvalifikationer og udvikle kompetencer. Fx vil en forelæsning, fx med et introducerende oplæg på e-læringsplatformen, være et godt valg til at introducere nye temaer, mens et gruppearbejde eller en online diskussion over længere tid med veldefinerede krav om deltagelse er vigtige undervisningsformer, når de studerende skal udvikle kompetencer i form af at kunne anvende de begreber, der er introduceret ved en forelæsning.

\section{Analysen trin for trin}

\section{Første trin: Analyse af uddannelsesmål}

I projektet vedrørende de to masteruddannelser bestod første trin i at analysere de tekster vedrørende uddannelsens opbygning, indhold, form og mål, der var stillet til rådighed fra uddannelsens side. Analyserne havde til formål at identificere uddannelsernes mål, herunder at opdele målene i kvalifikationsmål, kompetencemål og mål for faglig kommunikation.

Figur 3: Eksempel på grafisk fremstilling af resultatet af uddannelsesmåls-analyse. Eksemplet refererer til et fagelement, hvor de studerende både skal tilegne sig kvalifikationer og refleksions- og meningskompetencce, men hvor der ikke stilles krav om kommunikation med andre.

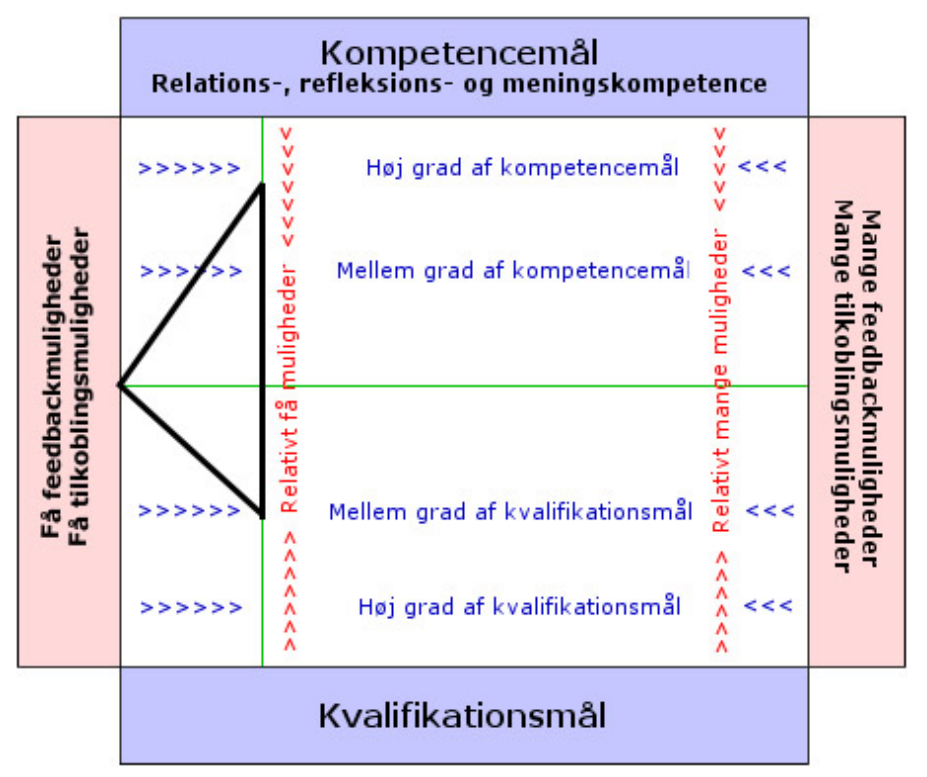




\section{Andet trin: Analyse af undervisningsformer}

På den anden side analyserede vi også 'uddannelses-teksterne' med henblik på identifikation af undervisningsformer. Disse kategoriserede vi som hhv. 1-M, 1-1, 1-mange og mangemange, så vi kunne pege på undervisningsformernes potentialer i relation til de studerendes læring.

Figur 4: Eksempel på grafisk fremstilling af tendensen i undervisningsformer. Den gule trekant refererer til lcesning af faglitteratur, den grønne til forelcesning, og den pink til gruppeøvelser og prcesentation.

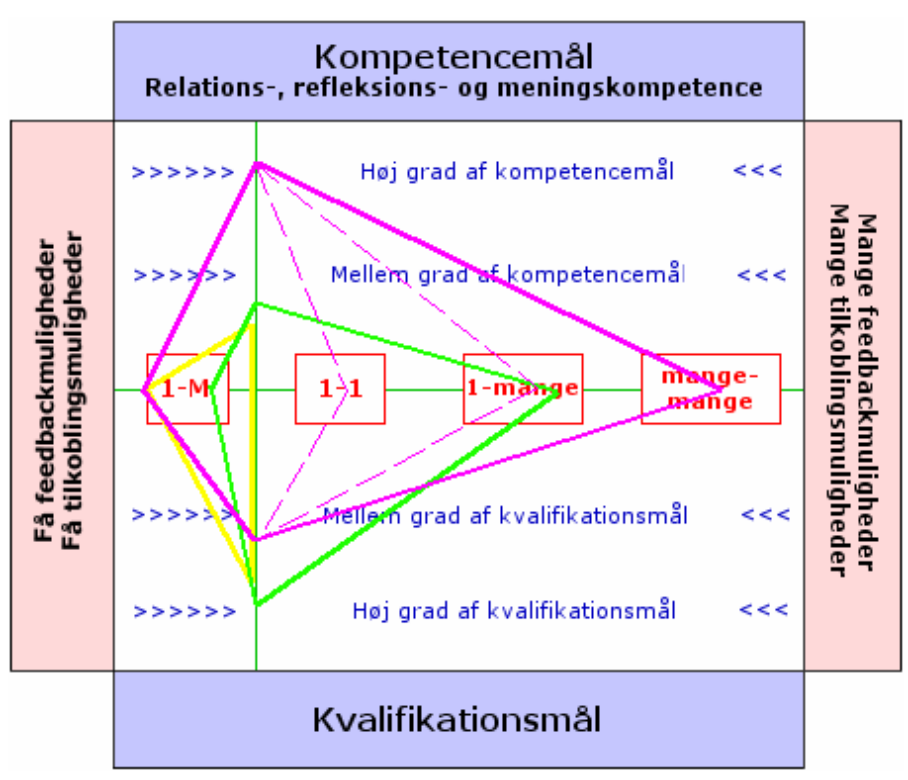

Tredje trin: Anbefaling af undervisningsformer med og uden it

De identificerede uddannelsesmål sammenlignede vi så med de identificerede undervisningsformer, for at undersøge om undervisningsformerne gav de studerende mulighed for at kunne nå de beskrevne uddannelsesmål. Vi stillede ikke spørgsmål ved de af uddannelsesledelsen beskrevne uddannelsesmål; vi søgte udelukkende at tilrette undervisningsformerne, så de passede bedst muligt til de opstillede uddannelsesmål.

Fandt vi god overensstemmelse mellem uddannelsesmål og undervisningsformer, kom vi med forslag til forbedringer fx i form af variation og komme med nogle bud på hvilke undervisningsformer, man med fordel kunne inddrage, og hvordan man med fordel kunne integrere IT i tilrettelæggelsen af undervisningen specielt i relation til brug af Blackboards mange undervisningsmæssige faciliteter.

Fandt vi 'dårlig' overensstemmelse eller måske slet ingen kom vi med bud på, hvordan undervisningen burde tilrettelægges, for at de studerende ville få god mulighed for at nå målene.

\section{Opsamling - og anbefalinger til andre, der vil prøve noget lignende}

Erfaringerne fra udviklingsprojektet har afgjort bekræftet vores tese om, at der kan komme noget rigtig godt ud af at gentænke et undervisningsforløbs tilrettelæggelse. Det har stor værdi at have fokus på god overensstemmelse mellem uddannelsesmål og undervisningsformer - og netop IT-støttede undervisningsformer kan være meget velegnede til opnåelse af en (stor) del af de uddannelsesmål, man typisk har i videregående uddannelser.

Vi mener også, at 'missing link-modellen' har vist sig som en god støtte i arbejdet med at analysere uddannelsesmål og udtænke passende undervisningsformer. Men om modellen ligefrem er en nødvendig forudsætning for at komme frem til de ønskede mål - det kan vi naturligvis ikke vide. 
Tidsskrift for universiteternes efter- og videreuddannelse (ISSN 1603-5518). 2 årgang, nr. 6, 2005

Andre, som vil give sig i kast med lignende udviklingsprojekter, kan måske drage nytte af nogle af de erfaringer, vi har gjort os sammen med underviserne i Masteruddannelsen i Rehabilitering.

For det første vil vi - endnu engang - slå fast, at det helt afgørende efter vores bedste overbevisning og erfaring er, at det styrende skal være målene for, hvad studerende skal have ud af uddannelsen. Undervisningsform - med og uden IT - følger herefter, sammen med materialevalget.

For det andet må vi advare mod, at man - hvis man vil bruge IT intensivt i undervisningen tager for let på introduktionen og vejledningen til de studerende om, hvordan den digitale læringsomgivelse bruges. I vores tilfælde troede vi, at det var gjort så godt som muligt, og i hvert fald tilstrækkeligt... men det var en stor del af de studerende tilsyneladende ikke enige i.

For det tredje må vi anbefale, at de studerende gives ikke bare gode, men MEGET gode muligheder for at orientere sig i den nye strukturering af uddannelsen, herunder de krav undervisningsformen stiller til dem. Det er, tyder vores erfaringer på, let at undervurdere usikkerhedsfølelsen hos studerende, der skal gennemgå et uddannelsesforløb med en uvant strukturering.

Og endelig, som det fjerde, må vi anbefale, at man gør sig klart, at en omlægning til mere intensiv udnyttelse af IT-støttede undervisningsformer ikke af sig selv medfører et reduceret timeforbrug hos underviserne. Dette må man forholde sig til; enten ved at tilføre tilstrækkelige ressourcer, eller ved at sætte nogle rammer, som fx sikrer undervisere mod at blive 'fanget' i meget tidskrævende deltagelse i digitale diskussionsfora.

\section{Tak til...}

Forfatterne til denne artikel takker særligt studieleder Christine Swane ${ }^{1}$ for konstruktivt samarbejde i alle faser af udviklingsarbejdet. Videre takker vi studielederen samt underviserne Jacob Hjelmborg ${ }^{2}$, Rene dePont Christensen ${ }^{2}$ og Jens Troelsen ${ }^{3}$ for i det hele taget at have haft lyst til at deltage i projektet, for at have taget positivt og konstruktivt imod forslag fra vores side, og for at have haft mod på at prøve ideerne af i praksis. Endelig takker vi uddannelsessekretær Tine Nielsen og studentermedhjælper Anne Dorte Wiberg for at have sørget for, at en række praktiske ting kunne falde på plads.

Udviklingsprojektet er gennemført med støtte fra Det Sundhedsvidenskabelige Fakultets Enhed for Uddannelsesudvikling, og delvist for midler bevilget fra Syddansk Universitets centrale e-læringsudviklingspulje.

\footnotetext{
${ }^{1}$ Forskningsenheden Helbred, Menneske, Samfund, Institut for Sundhedstjenesteforskning, Syddansk Universitet

${ }^{2}$ Forskningsenheden for Statistik, Syddansk Universitet

${ }^{3}$ Forskningsenheden Idræt, Krop og Sundhed, Institut for Idræt og Biomekanik, Syddansk Universitet
} 
Tidsskrift for universiteternes efter- og videreuddannelse (ISSN 1603-5518). 2 årgang, nr. 6, 2005

\section{Litteratur}

Bateson, Gregory. Steps to an ecology of mind - with a new foreword by Mary Catherine Bateson. Chicago: The University of Chicago Press, 2000.

Bruun, Bodil, Susanne Hjorth Hansen \& Jakob Ousager. Masteruddannelse i Gerontologi og Masteruddannelse i Rehabilitering - anbefalinger til IT-støttede undervisningsformer i uddannelsernes fælles Modul 1. Ikke publiceret, 2004

Bruun, Bodil, Susanne Hjorth Hansen \& Jakob Ousager. The missing link - i gråzonen mellem uddannelsesmål og undervisningsformer. Ikke publiceret masterspeciale, 2004

Keiding, Tina Bering, Erik Laursen \& Lene Østergaard Johansen. ”It og Bateson - et læringsteoretisk perspektiv.” It og læringsperspektiver. Ed. Helle Mathiasen. København: Alinea, 2003

Luhmann, Niklas. Sociale systemer - grundrids til en almen teori. København: Hans Reitzels Forlag, 2000

Mathiasen, Helle. Personlige bærbare computere i undervisningen. København: Danmarks Pædagogiske Universitet, 2002.

Poulsen, Morten Flate. Online education. Oslo: NKI Forlaget, 2003.

Qvortrup, Lars. “Viden og vidensformer - nye videnskabsteknologiske perspektiver.” Dialog og nærhet. IKT og undervisning. Eds. Yvonne Fritze, Geir Haugsbakk \& Yngve Troye Nordkvelle, Oslo: Høyskoleforlaget, 2003

Rasmussen, Jens. Undervisning i det refleksivt moderne. København: Hans Reitzels Forlag, 2004 